\title{
The reward value of saccharin solution prior to eating experience
}

\author{
PARSONS STATE HOSPITAL AND TRAINING CENTER, KANSAS
}

Newborn pigs ranging in age from 1 to $3 \mathrm{~h}$ old were tested for saccharin preference. The Ss had never eaten or drank prior to the test. They were allowed to choose between saccharin solution and water over a $24 h$ period. There was a significant preference for saccharin with the Ss drinking about two and one-half times as much saccharin as water. It was concluded that saccharin preference cannot be explained as being a secondary reinforcer.

Perhaps the best single argument against the needreductionists' "secondary reinforcement" explanation for saccharin preference was presented by Sheffield \& Roby (1950) who reasoned that if sweet taste is a secondary reinforcer, it should, as all other such reinforcers, lose its reinforcing properties if presented in the absence of the primary reinforcer (in this case, the nutritional properties of food). That is, if saccharin preference is learned, it can be extingulshed. Sheffield and Roby found that consummatory behavior did not extinguish.

Smith \& Capretta (1956) argued that Sheffield and Roby had not actually tested for extinction because food may have been in the Ss' stomachs at the time of saccharin ingestion. Foster (1968) argued that Sheffield and Roby had far too few extinction trials in light of the number of previously reinforced trials. Foster's study shortened the number of prior reinforcements, lengthened the amount of extinction time, and insured against the presence of food in the Ss' stomachs. Foster obtained the same findings as Sheffield and Roby (1.e., saccharin preference did not extinguish).

In the Hullian framework, a stimulus, which has been demonstrated to be reinforcing, must be classified as either a primary or a secondary reinforcer. Secondary reinforcers gain their reinforcing properties by being paired with primary reinforcers. If saccharin is a secondary reinforcer, it became so by being paired with a primary reinforcer (i.e., nutritional properties of food).

If it could be demonstrated that an organism would consistently choose a saccharin solution over tap water, before it had ever tasted any other substance (1.e., before it had eaten) it could safely be concluded that the preference was not due to prior learning and that saccharin was not a secondary reinforcer.

There are several practical problems involved in testing this line of reasoning. Ss must be newborn and naive with respect to eating experience. They must have sufficient neuromuscular development to be able to make a clearly defined choice response, and must have well developed gustatory sensitivity.
Information concerning gustatory sensitivity in the newborn is scarce and conflicting. Osepian (1958) reports that human infants can differentiate flavored solution by the third month. Jensen (1932) reports differentiation by the second day. Eckstein (1927) and Stirnimann (1936) report differentiation at birth. Eckstein even reports such differentiation in prematurely born infants. Pfaffmann (1935) found that sensitivity to sweetness developed about the 10th day in the cat. The rat can differentiate taste at one or two days (Small, 1899; Watson, 1907). This is at odds with Lane's (1917) findings that taste buds are not present for the first few days.

Newborn swine were chosen to serve as Ss in the present study because they are quite well developed at birth. The Ss were six ${ }^{1}$ newborn HampshireYorkshire crossbred pigs, and were from 1 to $3 \mathrm{~h}$ old at the beginning of the study. They were delivered by the experimenter, and separated from the mother without ever having eaten. All six Ss were from the same litter.

Six metal cages, $20 \times 20 \times 13$ in. with $1 / 2$ in. wire floors, were used. Within each cage were two 1,850 cc watering pans, one for saccharin and one for water. Precedure

Each $S$ was placed in a cage which contained two watering pans. One pan contained $900 \mathrm{cc}$ of water and the other contained $900 \mathrm{cc}$ of $1.3 \%$ saccharin solution. In three cages the saccharin was on the left and in the other three it was on the right. The Ss were allowed to choose freely between saccharin and water for $6 \mathrm{~h}$. At this time the pans were removed, the amount consumed was recorded, each was refilled to $900 \mathrm{cc}$, and then returned to the cage. This procedure was repeated at the end of 12,18 , and $24 \mathrm{~h}$. Only $900 \mathrm{cc}$ were placed in $1850 \mathrm{cc}$ pans to reduce the likelihood of spillage. No elaborate precautions were taken against spillage, but the lack of moisture under the pans indicates that no spillage took place.

Resulis

Seventy-two per cent of the total fluid intake was from the saccharin container and $28 \%$ was water. A $\mathrm{Z}$ test was conducted to test the hypothesis that the obtained proportions were drawn from a population with a known $p$ of .50 (i.e., a population with no preference for saccharin over water) (Senders, 1958). The results of the $Z$ test indicate a significant difference between saccharin and water consumption.

Sheffield \& Roby (1950) have argued that saccharin is not a secondary reinforcer. Smith \& Capretta (1956) have argued that it is. Foster (1968) replicated 
Sheffield and Roby's results and agreed with their conclusions. It can not be argued from the present study that saccharin preference is entirely unlearned. It can be concluded, however, that saccharin preference precedes learning even though the preference may be modifiable through learning.

References

ECKSTEIN, A. Zur physiologie der Geschmacksempfindung und des Sangreflexes bei Sanglingen. Zsch. F. Kinderbk., 1927, 45, 1-19.

FOSTER, R. Extinction of the consummatory response to a saccharin solution. Psychon. Sci. 1968, 10,81-82.

JENSEN, $K$. Differential reactions to taste and temperature stimuli in newborn infants. Genet. Psychol. Monogr., 1932, 12, 361.

LANE, H. H. The correlation between structure and function in the development of the special senses of the white rat. Ph. D. dissertation, 1917, cited in Munn, N. L., Handbook of Psychol. Research on the Rat. Boston: Houghton Mifflin, 1950, 12.

OSEPIAN, V. A. Razvitie funktsu vkusovogo (khimicheskogo) analisa- tora u detei pervogo goda shisni. Zh. vyssh nervn. Deiatel., 1958, 8 (6) 828.

PFAFFMANN, C. Differential responses of the newborn cat to gustatory stimuli. Psychol. Bull., 1935, 32, 697.

SENDERS, V. Measurement and Statistics. New York, Oxford University Press, 1958, 396.

SHEFFIELD, F. D., \& ROBY, T. B. Reward value of a non-nutritive sweet taste. J. comp. physiol. Psychol, 1950, 43, 471.

SMALL, W. S. Notes on the psychic development of the young white rat. Amer. J. Psychol, 1899, 2, 80.

SMITH, M. P., \& CAPRETTA, P. J. Effects of drive level and experience of the reward value of saccharin solutions. J. comp. physiol. Psychol, $1956,49,553$.

STIRNIMANN, F. Le gout et l'orderat du nouveau-ne. Rev. Franc. Pediat., 1936, 12, 73.

WATSON, J. B. Kinesthetic and organic sensations: Their role in the reactions of the white rat. Psychol. Rev. Monogr., 1907, 8, 2.

Note

1. One $S$ died during the fourth test period. 